\title{
REFLECTION OF THE ACQUIRED FORMAL EDUCATION OF TEACHERS FROM THE PERSPECTIVE OF THEIR VALUE ORIENTATION
}

\author{
Jiř́i Kropáč \\ Palacky University, Czech Republic \\ Iva Koribská \\ Palacky University, Czech Republic
}

\begin{abstract}
The article deals with the value orientation of teachers in the Czech Republic, who attempt to extend their formal education in the process of lifelong learning. The quality of the teacher directly influences the quality of the educational process, therefore the qualification of teachers has become the front theme of the international organisations. Lifelong Learning Centres as parts of the universities offer the programmes for teachers to extend their formal qualification. The primary aim of the article is to analyse teachers' value orientation reflected by the formal education.
\end{abstract}

Keywords: formal education, further education, lifelong learning, quality of education, values, value orientation.

\section{Introduction}

Teaching belongs to the dynamic professions and its changes, quality of the teachers' education and professional qualifications of teachers are in the spotlight of educational policy in Europe and the whole world. Teachers should reflect current social and regional needs, take the advantage of modern trends in the teaching process and encourage their students in their personal development. The quality of teaching process is the crucial precondition for the students' development. Quality improvement of the teaching can be realized only when all the participants of the educational process are motivated to a continuous improvement of the teaching process and share appropriate conditions and skills.

OECD report analysing key data on teachers in Europe (Eurydice, 2013) shows that most of the European countries consider further education of teachers as an individual professional duty. Besides, in some of the countries the professional development belongs to the compulsory components of the career progression and directly influences the teachers' salary. According to OECD report on teachers in Europe (Eurydice, 2013), in many of the European countries, schools are obliged to offer the concept of further education plans for their 
Jiři Kropáč, Iva Koribská. Reflection of the Acquired Formal Education of Teachers from the Perspective of their Value Orientation

employees, but less than one third of the countries require that teachers work up their personal further educational plans.

The support of quality teaching process and teacher as its key assumption is defined in many legislative documents. The Strategy of Educational Policy 2020 (MSMT, 2014) is generally based on the idea of lifelong learning and provides its conceptual basis for the Czech Republic. More specifically, the strategy states that for better learning process, everyday teaching and management activities in the school, it is necessary to modernize the teachers' training and contribute to the continual improvement of the teachers' pedagogical skills and their professional development in the course of their career.

Lifelong learning (not just of teachers) is planned, purposeful and institutionalized activity in the context of lifelong education, in which it is implemented what society deems important (Průcha, 2009). The values of society are thus passed on through further education to teachers, who according to their consideration try to interpret the knowledge to their pupils. The value orientation is a major determinant of behavior and human action and on the basis of their value preferences, we can estimate targeting of their activities or tendency and direction of their behavior (Horák, 1997). The individual values influence the choice of formal education courses for the teachers according to their personal requirements.

\section{Definition of Value and Value Orientation}

The socio-psychological conception describes value as a subjective evaluation or degree of the importance attributed by the individual to certain things, events, symbols and other people, and is acquired through the process of socialization and enculturation (Průcha et al., 2013, p. 92). From the psychological point of view, Nakonečný $(2009$, p. 45) speaks about the value as of what is good, in a broader sense of what is good and bad. From a sociological perspective Jandourek (2007, p. 97) defines value as a conscious or unconscious idea of what is desirable. Some values can be spoken of as "absolute", i.e. those who have a permanent character, such as moral values. Other values are shared only by specific groups according to the attribute of subjective importance. From this perspective, Spousta (2000, p. 17) defines value as "everything that has a price for us. Every true knowledge can be considered as value. Similarly, all positive, administrative norms that we benefit from or meet our noble desire, or those establishing democracy and humanism are values."

From the pedagogical perspective, education the value itself, because it contributes to forming of human beings and their lives and existences. According to Vališová and Kasíková (2011, p. 16) is the value of education in introducing to the relationship to the world, to people themselves, to other people, to Gods and 
their secrets. With acquiring of the values we create our value orientation. Value orientation is a hierarchical set of values adopted by person, group or company. This set represents a stable, coherent system of values that controls and regulates human behavior (Göbelová, 2008). Value system is formed by endogenous and exogenous factors.

According to Sak (2000) these are the following determinants:

- material conditions for life,

- social and educational institutions,

- influence of political and economic conditions of each country.

Social and economic changes are also reflected in the change of life values in the society. Veteška (Veteška \& Vacinová, 2011, p. 8) calls today's society turbulent. The distances are getting shorter, our life is accelerating, we are overwhelmed with information and material things become of more short-term, utilitarian character. Plamínek (2014, p. 51) mentions a change in the perception of life values, when honesty, obedience and faith are more likely to decline in the set of priorities and it is money, prestige and luxury that dominates. Plamínek argues, that it is the proper education that enables people to understand the world of today, teaches them to think independently and to focus on different values such as knowledge, a healthy environment, peace and security.

\section{The Value of Education and Formal Education}

Programming documents in the Czech Republic emphasize social and integrative character of education. There has been adopted a concept called lifelong learning for all, which is realized in a White Book and intends to connect the current school system and the sector of further education, employment and social policy, with emphasis on the efforts to integrate citizens into society (Veteška \& Vacínová, 2011, p. 46).

If we relate the value of education to the material world, the core of the value is in the ability to bring the material satisfaction. "It is the economic dimension of human life, which dominates in current society. Contemporary society therefore quite naturally sets the education as an instrument for ensuring material prosperity, respectively existence." (Veteška \& Vacínová, 2011, p. 43). Socioeconomic part of the research is focused on the economic value of the education, if it is possible to express this value in numbers.

Plamínek explains that education supports individualism and freedom and emphasizes empathy and insight that education can bring to the people. "Education is a deliberate, organized learning and it is a result of conscious efforts of educators. On the side of participants of education, learning can take place at the level of consciousness and unconsciousness. The best educational 
programmes hide under a layer of conscious learning - for example, under finding a solution of a problem or dispute - even unconscious layer of certain tendency development, that may later lead to the formation of habits. Thus, for example, a habit of thinking in context may be set up or the ability to see the issue through the eyes of the counterparty." (Plamínek, 2014, p. 35). The research questions analyze the value orientation from the perspective of teachers' personal development, whether they consider formal education as an intrapersonal satisfaction and motivation for professional growth.

Katrñák deals with the relationship of education and social inequality. From this perspective, he evaluates the education as an instrument of upward social mobility, acquisition of a new social status and social transformation of the origin into personal merit and individual abilities (Katrňák, 2004, p. 19). The research questions are formed in order to define the limitation factors of teachers' further education and to find out, whether the education is socially beneficial and if the preconceptions influence the value orientation of teachers.

Education of (not only) adults can be divided into formal, non-formal and informal. Formal education is purposeful, directed learning process and it is realized the in educational institutions whose functions, aim, content and the means and methods of assessment have a legislative definition (Barták, 2008, p. 12).

Generally, according to the Report on Adult Education Survey (2008) is formal education understood as an important value in the life. The answers of respondents demonstrate three main perspectives:

- a formal document of graduation (necessary in case of applying for a job),

- $\quad$ specific skill/ability crucial for labour market competetiveness as well as social assertion,

- „the basis”, general overview of historical and cultural context of human being and the society.

Above mentioned definitions of education and research results in formal education confirm that the value brought by (formal) education is a knowledge basis necessary for the profession, understanding of the outside world and a tool of socialization and integration. At the same time, education is seen as an abstract concept in the form of the document and the value of this document is understood as merely utilitarian.

\section{Methodology}

The survey has used quantitatively oriented design. A questionnaire has been used for data collection and the survey took place at the Pedagogical Faculty of Palacky University. The questionnaire was structured into first general part with 
questions focused on general perception of values and their necessity during the formal education of the teachers. The second part included questions focused on the factors that can set the limits of the value perception in the course of formal education, social and personal conception of the values of the teachers currently attending the courses of formal education.

With regards to the value perception of the teaching staff, the survey was realized by purposive choice of sample respondents, specifically students of combined studies. The total sample included 700 respondents. The analysis reflects the experience of ages between 22 years to 37 years by $79 \%$ and then 21 $\%$ of respondents between 38 years and more. The length of professional experience is mostly in the range of one to seven years of practice. Next is the teaching staff working in after-school clubs and other job placement defined by Ministry of Education, Youth and Sports legislation.

The offer of formal education at Palacký University, specialized on pedagogy and social studies, is considered as sufficient by majority of respondents, i.e. $81 \%$. From the perspective of the course offer specialized on pedagogy and social studies and their variability the majority of respondents $(74 \%)$ is also satisfied. From the professional point of view, the respondents, who consistently study to widen their professional competences, agree with the positive contribution to their future teaching practice. Another part, that analyses the intrapersonal perception of the values of teaching profession, reflects the results that are oriented on the relationship between understanding of identical values in relation to their course of study. The necessity of defining the values of the teaching profession is considered as important by $98 \%$ of respondents.

\section{The Survey Answers}

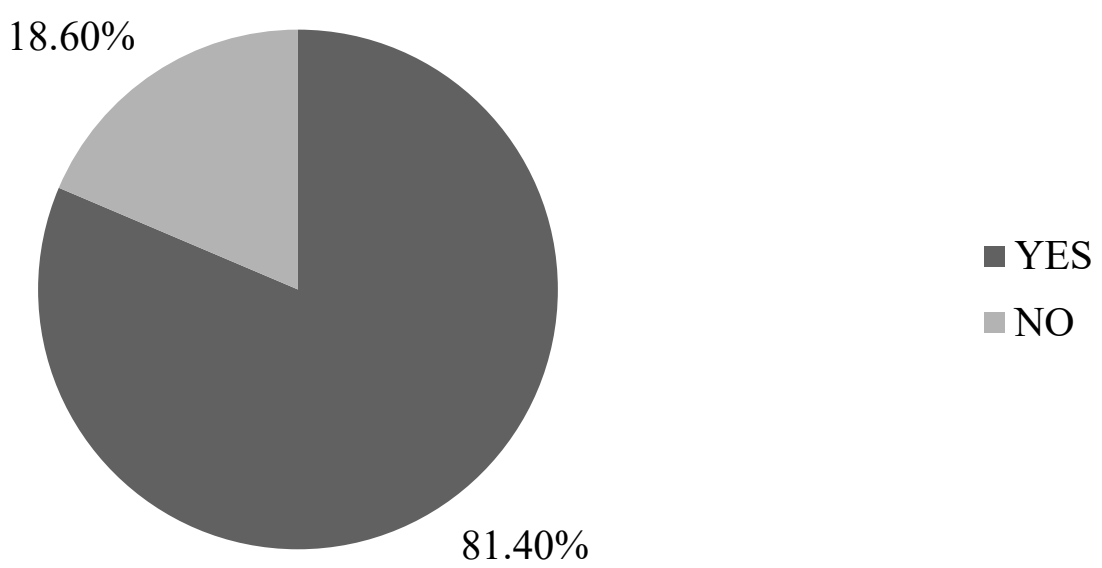

Figure 1 The Survey Answers on Formal Education Offer Sufficiency 
From the complex spectrum categorization of the value perception the results reflect the relationships among intrapersonal perception of the individual values, socio-economic values from the perspective of an institutional approach of achieved education defined by the legislation. The individual segments of a personal teachers' values were categorically evaluated by respondents according to subjective importance of the individuals and a majority of the respondents consider the value of life as the most important of all. Sociologically oriented part of the answers reflects tendency of modern people to incline to the cultural, religious and ethical roots. The decline of current ethical and religious value perception in relation to the education is quite significant. The results demonstrate secondary perception of traditional values and the declination of social responsibility, which reflects the value orientation of current generation teaching staff.

Professional growth and education is considered by respondents as the most important value needed for personal and socio-economic development. According to the survey results we can state that the value of education itself cannot be economically or materially expressed. In other words, $61 \%$ of respondents answered that this value cannot be economically or numerically characterized and unified. In the relation with economic value perception of teachers we focus on the legislation and state regulations. $56 \%$ of respondents answered that the growth of educational norms and regulations weakens their autonomy to make their own choice in further education development. The formation of the value system that can be applicable in teaching practice can be according to the $68 \%$ of respondents applicable also in the society as an useful system that will not be limited just by school area. Furthermore, the analysed data demonstrate that the individual is influenced the most by primary socialization and education in the family. This fact testifies the ability to absorb the perception of values by the individual and as an educator to convey the impact on the educated. The results reflect the importance of the educational institutions as a secondary factor influencing the individual education. We cannot even abandon the impact of informal education in cooperation with schools on the individual value formation.

Finally, the survey reflects the limitations that the teachers experience during their further education. According to $80 \%$ of respondents, the most common limitation is considered the time requirement of study process. With the time limitation is closely connected catchment area needed for education achieving. By catchment area is meant the commuting distance between the place of living and the educational institution. Furthermore, as significant limitations were mentioned also economic reasons including the transport costs, tuition fees etc. In a smaller scale of comparison we can detect other factors, such as limitations on the employer's side, legislative directives, the age of students. 


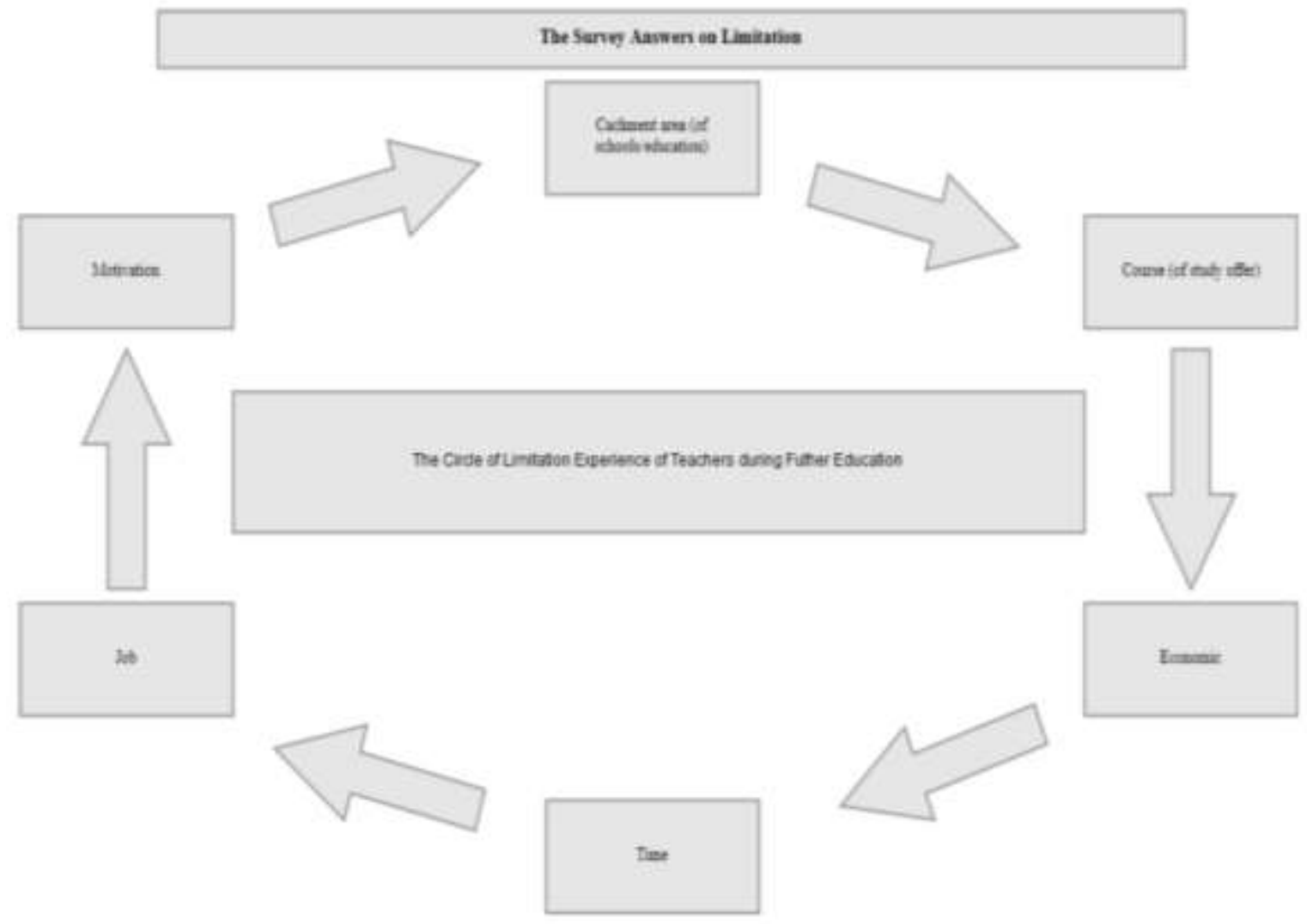

Figure 2 The Survey Answers on Limitation

\section{Conclusion and recommendations}

The article gives an insight into the perception of the current value orientation of teachers in the process of formal education. Reflection of value orientation of future teachers from the perspective of further education illustrates the current situation of teaching staff. The description of the acquired research data identifies various interdisciplinary approaches to the situation. The first part summarizes the psychological aspect of the individual in forming of subjective values. Then follows the socio-pedagogical reflection, in which we talk about connections (interconnection) of family values and individuals. Sociological point of view reflects the institutional concept of perception of values not only of future teachers, who can influence forming of the future values of their students as well as new generations of the society. Furthermore, we analyzed the limitation factors influencing the formal education. The values form the necessary basis of supposed behavior pattern of teachers. The perception of formal education value is not put aside, but traditional socio - cultural values of teachers tend to withdraw back to the consciousness of new teachers' generation. The system of values influences individual personalities, teachers including. 
Jiři Kropáč, Iva Koribská. Reflection of the Acquired Formal Education of Teachers from the Perspective of their Value Orientation

In the human society, the values have long-term fixed place. It is necessary to develop these characteristic attributes in the context of supposed teachers' skills (empathy, soft-skills etc.). We recommend to implement the development of interdisciplinary cross-skills into the formal education, consequently into the first training of teachers and further education.

\section{Acknowledgement}

This paper has been funded by IGA project of Palacký University Olomouc: Value of education among the students from different sociocultural environment (Grant number: IGA_PdF_2017_022).

\section{References}

Barták, J. (2008). Jak vzdělávat dospělé. Praha: Alfa nakladatelství.

Göbelová, T. (2008). Hodnotová výchova v pedagogické praxi. Ostrava: Ostravská univerzita.

Horák, J. (1997). Kapitoly z teorie výchovy I. a II. Problematika hodnot a hodnotové orientace I. dil. Liberec: TU v Liberci.

Jandourek, J. (2007). Sociologický slovník. Praha: Portál.

Katrňák, T. (2004). Odsouzeni k manuální práci. Praha: Sociologické nakladatelství.

Klíčové údaje o učitelích a ředitelích škol v Evropě. (2013). Downloaded from http://eacea.ec.europa.eu/education/eurydice/documents/key_data_series/151CS_HI.pdf

Kučerová, L. (2012). Hodnoty současné mladé populace. Diplomová práce. Brno: Masarykova Univerzita.

Makovská, K. (2013). Hodnoty a hodnotová orientace adolescenti̊. Diplomová práce. Brno: Mendelova Univerzita.

Mazáčová, N. (2014). Vybrané problémy obecné didaktiky. Praha: Univerzita Karlova

Nakonečný, M. (2009). Sociální psychologie. Praha: Academia.

Plamínek, J. (2014). Vzdělávání dospělých. Praha: Grada Publishing, a.s.

Průcha, J. (2014). Andragogický výzkum. Praha: Grada Publishing, a.s.

Průcha, J. (2009). Pedagogická encyklopedie. Praha: Portál.

Průcha, J., Walterová, E., \& Mareš, J. (2013). Pedagogický slovník. Praha: Portál.

Sak, P. (2000). Proměny české mládeže (česká mládež v pohledu sociologických výzkumů). Praha: Petrklíč.

Spousta, V. (2000). Vádemékum autora odborné a vědecké práce (se zaměrením na práce pedagogické). Brno: Masarykova univerzita.

Strategie vzdělávací politiky 2020. (2014). Downloaded from http://www.msmt.cz/vzdelavani/ skolstvi-v-cr/strategicke-a-koncepcni-dokumenty-cerven-2009

Švaříček, R., Šed'ová, K. et al. (2007). Kvalitativní výzkum v pedagogických vědách. Praha: Portál.

Vališová, A., \& Kasíková, H. (2011). Pedagogika pro učitele. Praha: Grada Publishing, a.s.

Veteška, J. (2016). Přrehled andragogiky. Praha: Portál.

Veteška, J. Vacínová, T. et al. (2011). Aktuální otázky vzdělávání dospělých. Andragogika na prahu 21. století. Praha: Univerzita Jana Amose Komenského.

Zpráva Z průzkumu vzdělávání dospělích V ČR (2008). Downloaded from http://www.msmt.cz/vzdelavani/dalsi-vzdelavani/zprava-z-pruzkumuvzdelavanidospelych-v-cr 